\title{
Impacts of Fuel Subsidies in ANGOLA on the Instability of the Fuel Market in the DRC : A Case Study of the Western Supply Route in DRC
}

\author{
Yondo Ngandu Vially \& Bukasa Muamba link \\ Faculty of Oil, Gas and Renewable Energy \\ University of Kinshasa, DR Congo
}

\begin{abstract}
In this article, we have studied the unintended effects of petroleum product subsidies in Angola in the development of fraud and smuggling in the Democratic Republic of Congo as well as its consequences on the economic life of the DRC, at least for the track supply from western DRC. The relatively weak porosity and security at the Congolese borders facilitate the development of the illicit trade in petroleum products between Angola and the DRC. This extensive trade is explained by the price disparities on both sides of the borders. exchange rates, differences in energy policies and fiscal variations between the two countries have contributed to creating a noticeable gap between prices in Angola and prices in DRC. There are, of course, no official records to quantify these flows. the direct estimation methods through the counting of vehicles, drums, cans, etc. lack reliability, in particular due to the insufficient geographical and temporal coverage: the fuel fraud circuits are relatively diversified and characterized by high variability over time which would require permanent observation, too cumbersome to implement.
\end{abstract}

These fuels are illegally imported from Angola, where they are highly subsidized. This illegal market constitutes a major source of income for young people, generally deprived of a decent job, in the trade of street vendors by generally exhibiting bottles and cans on street corners at prices generally $30 \%$ lower than the prices of stations -service official. In addition, smugglers have entered the official distribution network through service stations scattered throughout the country's major cities. the consequences of these fraudulent activities on the economic life of the DRC are incalculable, especially since the politico-military authorities of the DRC are complicit

Keywords : Subsidies, Smuggling, Fuel, Fraud.

\section{INTRODUCTION}

In recent years, we have witnessed an evolution of the vehicle fleet towards an increasing use of vehicles equipped with diesel engines. This trend is very marked in Africa where the automobile fleet is dominated by the diesel engine. Furthermore, the tendency for pollution and particulate emissions from engines is related to the running time of an engine, the older the engine the more it pollutes. [1]

Various governments impose taxes on petroleum products to generate revenue to finance public goods and services for the benefit of citizens. They also support the poor through oil subsidies. The unintended effect of these subsidies is that the price differences they create induce unscrupulous individuals to engage in various forms of fuel fraud. These include trafficking, adulteration, fuel dilution and diversion. In reality, fuel fraud is a cross-border problem where lower quality and cheaper products are smuggled into neighboring countries where they are sold at higher prices. [2]

Attempts were made in the past to avoid fraud and counter-tape by marking fuels with dyes around the 1950s. This method was easily bypassed by simple and inexpensive methods of bleaching dyes. however, new technologies using chemical markers as part of a comprehensive fuel supply chain protection program have proven effective in reducing existing criminal activity and deterring others. unfortunately the practical implementation of tagging methods still poses serious problems in most African countries. [3]

When a fuel is mixed with other inferior products, the quality of the fuel is impaired and therefore no longer burns completely in the engine. this means that money that could have been used for profitable investments is instead lost in maintenance costs. 


\section{STUDY CONTEXT}

\subsection{GEOGRAPHICAL SITUATION OF ANGOLA AND DRC}

DRC and ANGOLA are member countries of SADEC (Southern African Development Community), which is an organization that aims to promote the economic development of southern Africa

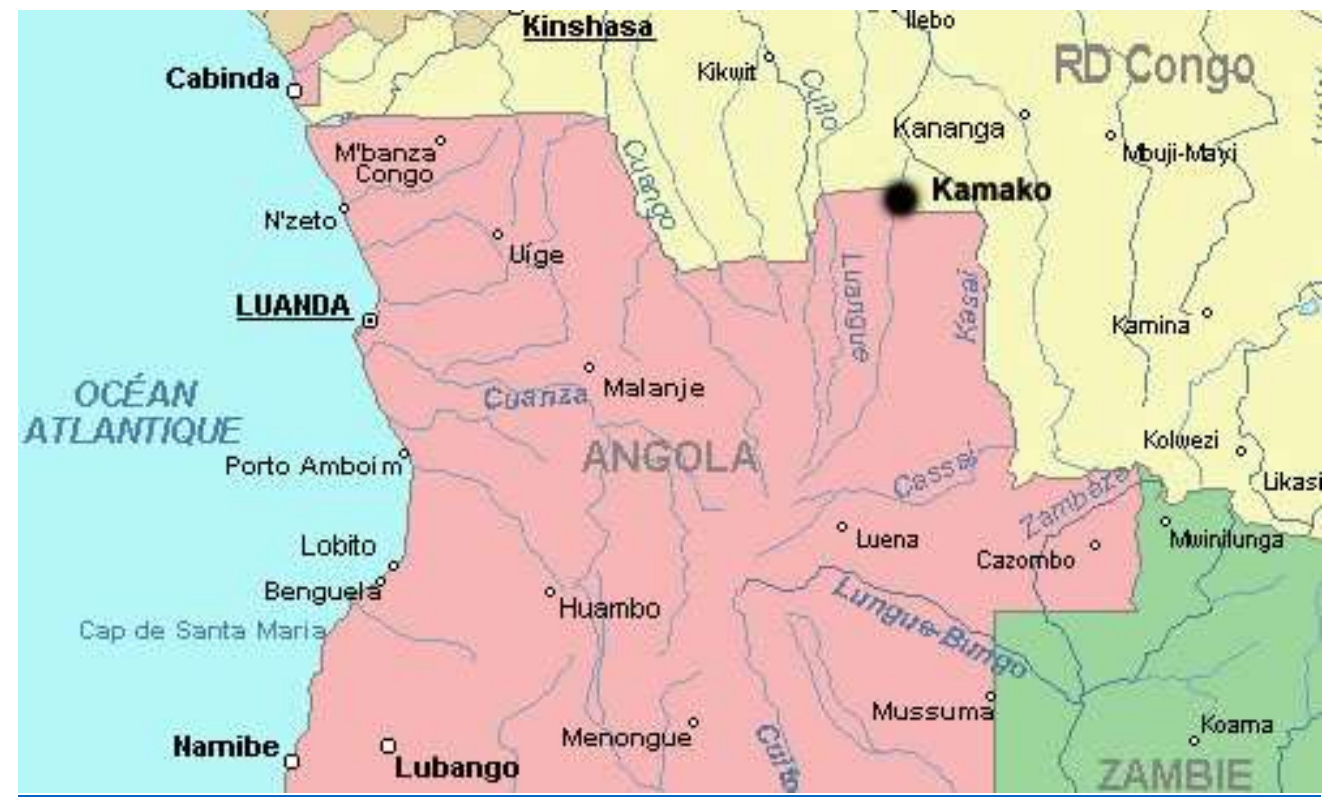

Fig.1 : Geographical situation of these two contries

The two countries share a discontinuous international land border of 2,511 kilometers which distinguishes the territory of Angola and that of the Democratic Republic of Congo in Central Africa. The border between the two countries is made up of two distinct segments :

$>$ The main segment is located in the southwest of the Democratic Republic of the Congo. It begins in the east at the tripoint it forms with the Angola / Zambia and Zambia / Democratic Republic of Congo borders. it then follows an irregular course marked by several right angles before reaching the Congolese port of Matadi located on the Congo River, which it will follow until its mouth in the Atlantic Ocean to the northwest;

$>$ The smallest part of the border which separates the Angolan exclave of Cabinda from the democratic republic of the Congo is not far: it is about $20 \mathrm{~km}$ north of the mouth of the Congo, and stretches to a tripoint that it forms with the borders which delimits the two Congos ,as well as that between Angola and Congo-Brazzaville.

Access to the sea for the Democratic Republic of the Congo is very restricted and the delimitation of maritime borders can only be done with Angola (presence of the Angolan exclave of Cabinda in the North, and of Angola itself. even in the south). It turns out that this delimitation never took place.

\subsection{Angola Fuel and Subsidies Sector}

Angola produces more than 1.4 million barrels of crude per day, just behind Nigeria. But since the country currently only has one refinery, most of its crude is refined abroad. Angola imports about $80 \%$ of the petroleum derivatives it consumes due to lack of refining capacity. Sonangol is a public company responsible for the exploitation and production of oil and natural gas in Angola. the group is the main company in Angola, it represents almost 40\% third of the GDP of the country and 95\% of exports.

Despite Angola's leading role as an oil producer on the African continent, various technical and operational constraints have resulted in reduced oil and liquefied natural gas production in recent years. downstream in the row, Angola imports large volumes of fuels and lubricants, either due to lack of refining capacity, or due to storage limitations. [4]

in 2019, the country had a storage capacity on operational land of 676,085 m 3 (six hundred and seventy-six thousand eighty-five cubic meters) and with a number of operational service stations of 971 (nine hundred and seventy-one)

Table. 1 : Distribution of service stations by Province [4] 
International Journal of Advances in Scientific Research and Engineering (ijasre), Vol 7 (1), January -2021

\begin{tabular}{|c|c|}
\hline PROVINCES & Number of Station \\
\hline BENGO & 16 \\
\hline BENGUELA & 112 \\
\hline BIÉ & 25 \\
\hline CABINDA & 37 \\
\hline CUNENE & 14 \\
\hline HUAMBO & 72 \\
\hline HUILA & 75 \\
\hline CUANZA CUBANGO & 11 \\
\hline KUANZA SUL & 42 \\
\hline KUANZA NORTE & 10 \\
\hline LUANDA & 356 \\
\hline LUANDA SUL & 12 \\
\hline LUANDA NORTE & 28 \\
\hline MALANJE & 28 \\
\hline MEXICO & 30 \\
\hline NAMIBE & 21 \\
\hline UÍGE & 32 \\
\hline ZAÏRE & 50 \\
\hline TOTAL & 971 \\
\hline
\end{tabular}

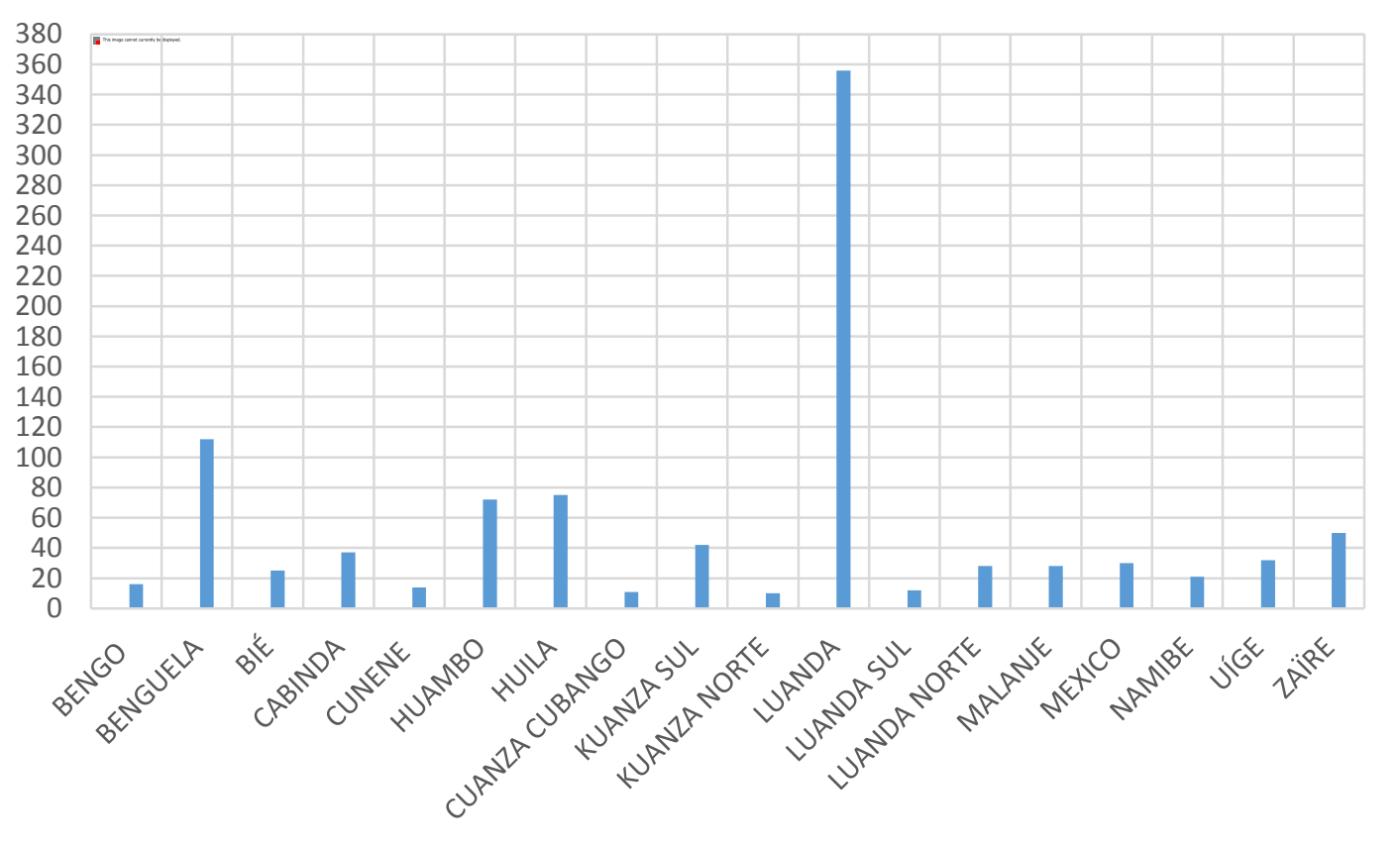

Fig.2 : Distribution of Service stations by province

2.2.1. Price Policy and Subsidies 
Fuels in Angola are heavily subsidized and SONANGOL spends around 2 billion dollars per year for the consumer to pay for the fuel at the current price at the pump distributed as:

$>$ Gasoline: $160 \mathrm{Kwanza} /$ liter (i.e. \$ 0.33 / liter)

$>$ diesel: $135 \mathrm{Kwanza} /$ liter (i.e. \$ 0.28 / liter)

$>$ Kerosene: 70 Kwanza / liter (i.e. \$ 0.15 / liter)

The exchange rate at the start of 2020 is: $\$ 1=$ Kwanza 478.281

Indeed, gasoline and diesel prices have increased by $39 \%$ and $80 \%$, respectively. a liter of gasoline now costs consumers 160 kwanzas while a liter of diesel costs 135 kwanzas. This spike in fuel prices is the third recorded in Angola since September 2014. In February 2015, the Angolan government revised upwards its budget deficit projections for the current year and announced its intention to cut budget spending. [5]

this gradual reduction in fuel subsidies would have saved the southern African country 110 billion kwanzas (around \$ 1 billion) since October, reveals the statement from the Ministry of Finance and in 2013, fuel subsidies accounted for $4 \%$ of country budget. According to the Angolan finance ministry, this price increase is intended to ease the burden of subsidies as the current oil crisis has led to a decrease in the country's revenue, which has resulted in a reduction in the budget for public spending. fuel price subsidies have since become a burden that the Angolan state can no longer ignore.

The sharp drop in global crude prices also weighed heavily on the local currency, which fell more than $30 \%$ against the dollar in 2015 .

In addition, the Angolan government has announced the increase in fuel subsidies in the agriculture and fisheries sector to $45 \%$.

\subsection{DRC FUEL SECTOR}

\subsubsection{Procurement}

Since 1995, the Raffinerie de la RDC (SOCIR: Société Congolaise des Industrie de Raffinage) no longer operates; Thus, the supply of Petroleum Products is made entirely through imports of Refined Products. the supply of the country is done from three main routes:

$>$ West route, which represents $85 \%$ of supplies

$>$ Southern Way

$>$ East Way

The West is the most structured supply route and alone accounts for over $85 \%$ of national supplies. thanks to its opening to the Atlantic Ocean, it allows regular access to oil tankers. It starts at the mouth of the Congo River to take the main destination of Kinshasa with the following modes of transport:

$>$ Seaway (Arrival of Ships at the Atlantic Ocean)

$>$ Waterway (Lightening by Barge)

$>$ By Pipeline

$>$ Roadway

\subsubsection{Stakeholders in the Western Supply Path}

$>$ The Congolese State

$>$ Approved Importers

$>$ Oil Terminals

$>$ Commercial companies 
$>$ Authorized carriers

$>$ The Smugglers

\subsubsection{Supply System infrastructure}

The infrastructure of the petroleum product supply and distribution system in the DRC is made up of the following main facilities: [6]

> Tanker Loading / Unloading port facilities: These are public and private oil terminals (SOCIR, SEP CONGO, KUNTUALA TERMINAL, LEREXCOM)

$>$ The SOCIR refinery: Although the refining activity is closed, SOCIR has enormous storage capacities (160,000 m3) and adequate logistical resources

$>$ A flotilla in the maritime zone, made up of several barges and Pushers on behalf of the Petroleum Terminals to participate in the river transport from Moanda to Matadi via Boma

$>$ Two 6-inch Matadi - Kinshasa pipelines, with a nominal transit capacity of 1,400,000 m3 / year

$>$ Several tanker trucks to ensure road transport

\subsubsection{Land-based fuel pricing mechanism in the DRC}

The decree-law of March 20, 1961 relating to prices, as amended by ordinance Law n ${ }^{\circ} 83-026$ of September 12, 1983, stipulates that in the DRC, the fixing of the prices of goods and services falls within the domain of the owners of these so-called goods and services. however, an exception is made for certain products, among which we cite terrestrial fuels because of their strategic nature in the national economy. [7]

The state's view of the price of land fuels is carried out not only by the Ministry of Hydrocarbons (supervising ministry), but also by the Ministry of the National Economy through the price structure monitoring committee.

The land fuel price structure gives the prices for different types of land fuels used in the Country depending on whether those fuels will have come in each of the Country's three supply routes

\subsubsection{Price structure of land fuels in the DRC}

the price structure of land fuels can be defined as a table consisting of the following elements: [8]

Average Frontier Price (PMF): This is the average of the prices of different cargoes of fuels imported by various suppliers weighted by the quantities of these cargoes

$>$ Distribution costs: They consist on the one hand of the quotas of the various stakeholders other than the State: SOCIR, the National Energy Commission and SEP CONGO, and on the other hand the resources of commercial oil companies, that is, their commercial charges and their profit margin

$>$ Strategic stock: It is a form of reserve, either in kind or in cash, that the State builds in order to face a given situation

$>$ Taxation: It consists of customs and Assizes

$>$ Parafiscality: It is mainly composed of the transport surcharge

$>$ safety stock: Represents all the charges allocated to reimbursement of losses and loss of earnings incurred by operators in the fuel sector

$>$ FONER: Road maintenance fund

$>$ Exchange rate

\subsubsection{Prices of land fuels in the DRC}


International Journal of Advances in Scientific Research and Engineering (ijasre), Vol 7 (1), January -2021

According to ministerial decree $\mathrm{n}^{\circ} 0012$ / CAB / MIN / ECONAT / ABM / RKS / MSM / 2020 of August 12, 2020 fixing the prices of land fuels, the price structure is as follows: [9]

Table.2 : Price of land Fuels in the DRC

\begin{tabular}{|l|l|l|l|l|l|l|}
\hline \multicolumn{1}{|c|}{ Fuel } & \multicolumn{5}{c|}{ Price per zone } \\
\hline & \multicolumn{2}{|c|}{ West } & \multicolumn{2}{c|}{ East } & \multicolumn{2}{c|}{ South } \\
\hline & CDF & USD & CDF & USD & CDF & USD \\
\hline Gasoline & $1995 \mathrm{FC}$ & $1,014 \$$ & $1810 \mathrm{FC}$ & $0,920 \$$ & $1760 \mathrm{FC}$ & $0,894 \$$ \\
\hline Gasoil & $1985 \mathrm{FC}$ & $1,010 \$$ & $1820 \mathrm{FC}$ & $0,925 \$$ & $1750 \mathrm{FC}$ & $0,889 \$$ \\
\hline Jet A1 & $1982 \mathrm{FC}$ & $1,007 \$$ & $2236 \mathrm{FC}$ & $1,137 \$$ & $2168 \mathrm{FC}$ & $1,102 \$$ \\
\hline
\end{tabular}

\section{IMPACT OF FUEL SUBSIDIES IN ANGOLA ON OIL FRAUD IN DRC}

3.1. The price differential between Angola and the Countries of the SADEC sub-region in 2019. [10]

Table.3 : Difference in land fuel Prices between SADEC countries

\begin{tabular}{|c|c|c|}
\hline COUNTRY & \multicolumn{2}{|c|}{ PRICE (\$) } \\
\hline & GASOLINE & GASOIL \\
\hline ANGOLA & $0,33 \$$ & $0,28 \$$ \\
\hline ZAMBIA & $0,72 \$$ & $0,64 \$$ \\
\hline ZIMBABWE & $0,78 \$$ & $0,81 \$$ \\
\hline BOTSWANA & $0,85 \$$ & $0,84 \$$ \\
\hline LESOTHO & $0,88 \$$ & $0,94 \$$ \\
\hline SWAZILAND & $0,88 \$$ & $0,88 \$$ \\
\hline NAMIBIA & $0,89 \$$ & $0,93 \$$ \\
\hline MOZAMBIQUE & $1,04 \$$ & $0,99 \$$ \\
\hline SOUTH AFRICA & $1,08 \$$ & $1,13 \$$ \\
\hline MADAGASCAR & $1,12 \$$ & $0,93 \$$ \\
\hline MALAWI & $1,19 \$$ & $1,19 \$$ \\
\hline MAURITANIA & $1,20 \$$ & $0,96 \$$ \\
\hline DRC & $1,36 \$$ & $1,34 \$$ \\
\hline
\end{tabular}

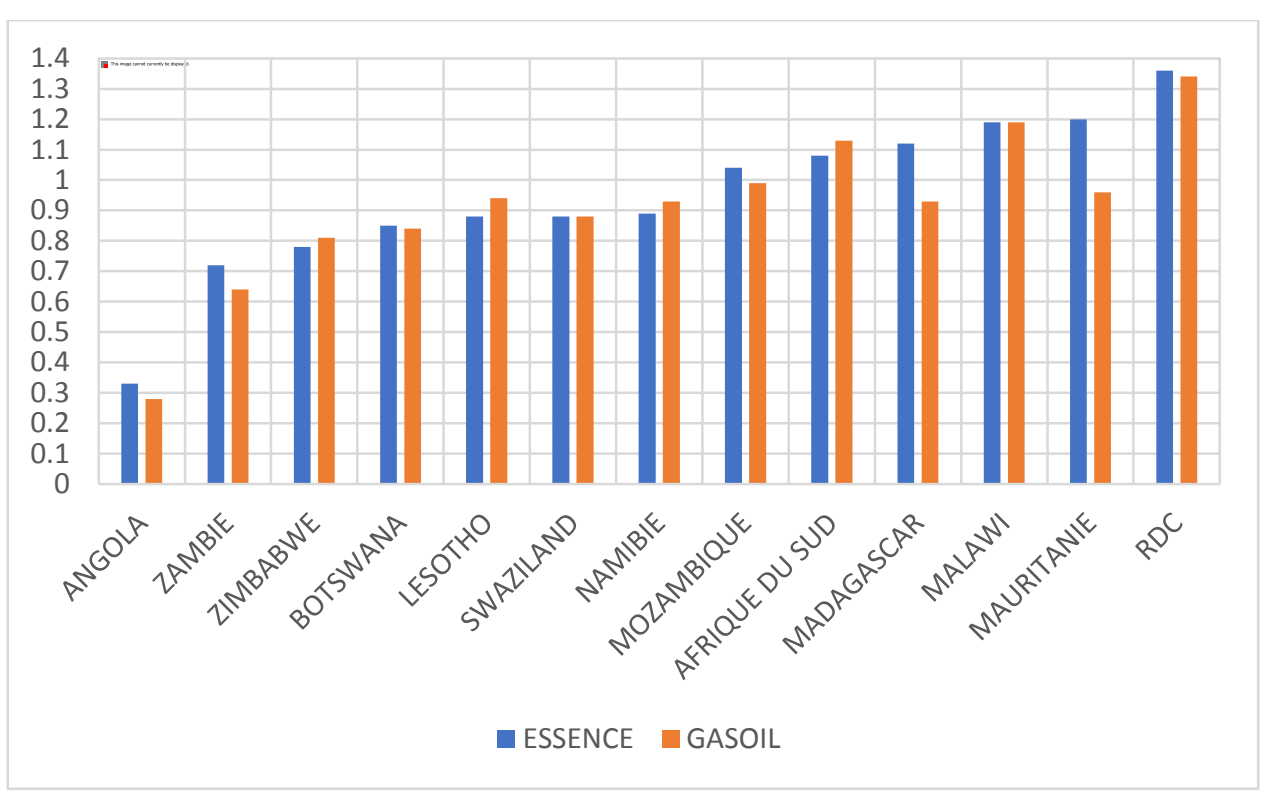

Fig.3 : Difference in land fuel Prices between SADEC countries

The figure above shows the difference in land fuel prices between Angola and the DRC.

A posteriori, two conditions seem to have been necessary for the development of traffic in this context: 
$>$ first of all, merchant profit margins have reached their highest level

$>$ Then, the laxity that characterizes Congolese leaders and the lack of state authority

There is a lack of rigor in the basic formalities involved in the approval of importers of petroleum products at borders. Actors apply the rules they consider appropriate because there are often no standards set by the regulator. the gap between regulatory provisions and current practices is really high

\subsection{Organization of Fraud at the DRC-Angola Borders}

the unintended effect of the subsidies in Angola on the DRC is that the price differences they create encourage unscrupulous individuals to engage in various forms of fuel fraud in the Congolese borders including YEMA, YACHT, LUFU... as well as in some ports clandestine people created for the need of the cause. These include traffic, fuel adulteration and dilution, fuel diversion in transit and round-tripping:

$>$ Lower quality and cheaper products are smuggled (as adulterant or subsidized fuel) to the DRC where they are sold at higher prices.

$>$ Kerosene, inexpensive in Angola and whose market is not sufficiently fluid in the DRC, is mixed with diesel by adulteration and dilution in order to gain more profit

$>$ Fuel shipments are not analyzed in the lab to ensure compliance with the law

$>$ Some cargoes are sometimes mixed with water to escape the vigilance of customs controllers and subsequently separate the fuel from the water by simple decantation

$>$ Some cargoes do not pay customs or tax due to false exemptions presented to border services

$>$ Land borders being militarized zones, the administration often suffers from the dicta of the military. Some army generals and colonels abuse their influence to smuggle fuel shipments without paying taxes or customs

As the control procedures are not structured at the borders, it is impossible to make exact accounts of the volumes which pass from Angola to the Democratic Republic of Congo. Hence the illicit enrichment of state service agents committed to this service

\subsection{Existence of a black market in fuels between the two countries}

There is a black market in fuels that has developed between Angola and the DRC due to the maintenance of an official administered price and chronic shortages due to technical and organizational problems. in this market where the traders (traffickers) who supply fraud circuits in the DRC get their supplies, prices fluctuate freely and are well above the official prices applied in Angola. this black market is maintained by several of the Congolese generals who, in addition to the army, have made fuel trafficking their livelihood. there are also ministers, political figures and influential men of the country who generally use their function or authority to avoid taxation.

The differences between official prices make this business attractive because they allow a fairly large gross profit margin to be generated which will then be shared on both sides of the border, between authorities and traders.

\subsection{Impacts on the fuel market balance in the DRC}

the traffickers involved in the black market established between the two countries, have set up a true parallel supply chain which, at a certain level, fits into the national supply circuit. these traffickers have distribution networks through service stations scattered throughout the city of Kinshasa. taking into account the fuel price policy in the DRC through the price structure, where the component is determined by the average of the prices of the different cargoes of fuels imported by various suppliers weighted by the quantities of these cargoes, only forregular, traceable and legal imports.in the event that the imported cargoes originate from smuggling and border fraud activities as is the case in this study, the quantities imported, although ultimately ending up in the supply chain to consumers, are not counted in the official price structure. Therefore, there will be unfair competition in the fuel market in that smugglers are free to set their prices according to their profit margin. in order to meet national demand, two competing sources of fuel coexist: the relatively atomized informal circuit and the formal circuit represented by the state monopoly. insofar as total demand remains constant, the two circuits operate on the principle of communicating vessels: when informal supply increases, official sales decrease and vice versa

in addition, it is also installed on the fuel distribution network, in parallel with the network of service stations which is a formal circuit for the sale of fuels, a network of itinerant sellers of fuels resulting from these activities (informal circuit) of against band 
International Journal of Advances in Scientific Research and Engineering (ijasre), Vol 7 (1), January -2021

and practicing prices without competition compared to service stations. A parallel market for the distribution of fuels is thus established.

Table.4 : Différence betwen prices on the official market and on the parallel market. [11]

\begin{tabular}{|c|c|c|c|c|c|c|c|c|c|}
\hline \multirow[t]{3}{*}{ Périod } & \multirow{3}{*}{\begin{tabular}{|c|} 
exchange rate \\
$\$$ \\
\end{tabular}} & \multicolumn{4}{|c|}{ GASOLINE } & \multicolumn{4}{|c|}{ GASOIL } \\
\hline & & \multicolumn{2}{|c|}{ Official Market Price } & \multicolumn{2}{|c|}{ Parallel Market Price } & \multicolumn{2}{|c|}{ Official Market Price } & \multicolumn{2}{|c|}{ Parallel Market Price } \\
\hline & & CDF & $\$$ & CDF & $\$$ & CDF & $\$$ & CDF & $\$$ \\
\hline Jul-14 & 937,86 & 1475,00 & 1,5727 & 950,00 & 1,0129 & 1465,00 & 1,5621 & 920,00 & 0,9810 \\
\hline Sep-14 & 934,10 & 1525,00 & 1,632 & 950,00 & 1,0170 & 1515,00 & 1,6213 & 920,00 & 0,9849 \\
\hline Jan-15 & 932,43 & 1440,00 & 1,5443 & 950,00 & 1,0188 & 1430,00 & 1,5336 & 920,00 & 0,9867 \\
\hline May-15 & 933,82 & 1440,00 & 1,5424 & 950,00 & 1,0173 & 1430,00 & 1,5317 & 920,00 & 0,9852 \\
\hline Nov-15 & 935,66 & 1440,00 & 1,539 & 950,00 & 1,0153 & 1430,00 & 1,5283 & 920,00 & 0,9833 \\
\hline Feb-16 & 939,76 & 1440,00 & 1,5323 & 975,00 & 1,0375 & 1430,00 & 1,5217 & 930,00 & 0,9896 \\
\hline Aug-16 & 1050,00 & 1490,00 & 1,419 & 975,00 & 0,9286 & 1480,00 & 1,4095 & 930,00 & 0,8857 \\
\hline Sep-16 & 1050,00 & 1540,00 & 1,4667 & 1000,00 & 0,9524 & 1530,00 & 1,4571 & 980,00 & 0,9333 \\
\hline Nov-16 & 1154,00 & 1540,00 & 1,3345 & 1000,00 & 0,8666 & 1530,00 & 1,3258 & 980,00 & 0,8492 \\
\hline Feb-17 & 1320,00 & 1615,00 & 1,2235 & 1050,00 & 0,7955 & 1605,00 & 1,2159 & 980,00 & 0,7424 \\
\hline Mar-17 & 1320,00 & 1650,00 & 1,25 & 1050,00 & 0,7955 & 1640,00 & 1,2424 & 990,00 & 0,7500 \\
\hline Jun-17 & 1380,00 & 1730,00 & 1,2536 & 1200,00 & 0,8696 & 1720,00 & 1,2464 & 1000,00 & 0,7246 \\
\hline Jan-18 & 1604,00 & 1810,00 & 1,1284 & 1350,00 & 0,8416 & 1800,00 & 1,1221 & 1050,00 & 0,6546 \\
\hline Mar-18 & 1620,00 & 1890,00 & 1,1667 & 1400,00 & 0,8642 & 1880,00 & 1,1604 & 1100,00 & 0,6790 \\
\hline Apr-18 & 1620,00 & 1980,00 & 1,2222 & 1400,00 & 0,8642 & 1970,00 & 1,216 & 1100,00 & 0,6790 \\
\hline Sep-18 & 1676,00 & 2110,00 & 1,2589 & 1550,00 & 0,9248 & 2100,00 & 1,2529 & 1200,00 & 0,7160 \\
\hline Nov-18 & 1665,00 & 2240,00 & 1,3453 & 1550,00 & 0,9309 & 2230,00 & 1,3393 & 1200,00 & 0,7207 \\
\hline May-20 & 1837,00 & 1995,00 & 1,086 & 1400,00 & 0,7621 & 1985,00 & 1,08 & 1150,00 & 0,6260 \\
\hline
\end{tabular}

\section{GASOLINE}

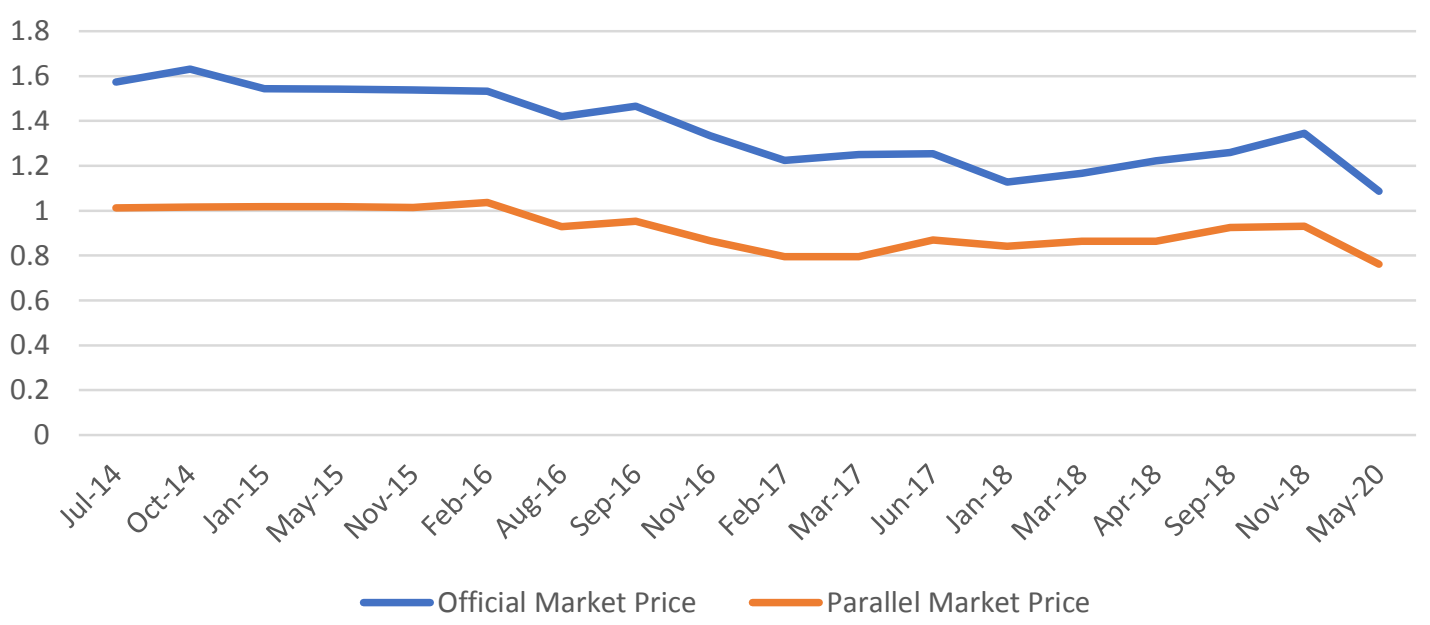

Fig.4 : Variation in Gasoline Prices betwen the officialmarket and the parallel market 


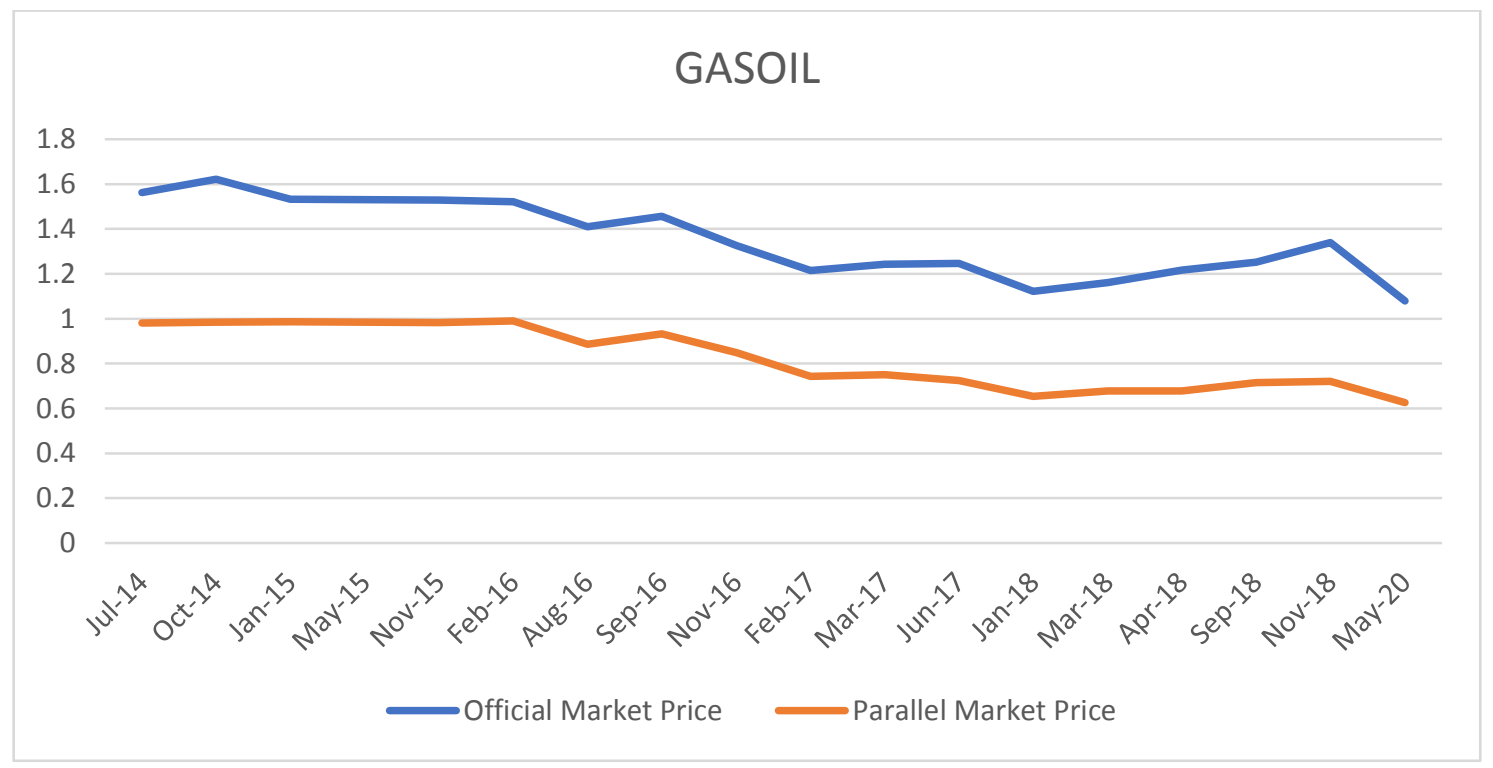

Fig.5 : Variation in Gasoil Prices betwen the officialmarket and the parallel market

\section{CONCLUSION}

During this study, we have demonstrated how the fuel subsidies applied in ANGOLA favor the development of fraud and smuggling activities in the DRC with as a direct consequence the instability of the fuel market in the DRC in the western supply route.

The porosity and relatively low security at the Congolese borders facilitate the development of illicit trade in petroleum products between Angola and the DRC. This extensive trade is explained by the price disparities on both sides of the borders. Exchange rates, differences in energy policies and fiscal variations between the two countries have contributed to creating a noticeable gap between prices in Angola and prices in DRC. There are, of course, no official records to quantify these flows. The direct estimation methods through the counting of vehicles, drums, cans, etc. lack reliability, in particular due to the insufficiency in geographical and temporal coverage: the circuits of fuel fraud are relatively diversified and characterized. by a strong variability over time which would require permanent observation, too cumbersome to set up

\section{REFERENCES}

1. IMANI AFRICA, Comment prévenir la fraude des produits pétroliers en Afrique, Ghana 2017

2. Kevin McKenna. ( $2^{\text {nd }}$ Mach, 2016), Approaches to combating illicit Fuel Trade and Fraud : Evidence from the Authentix Experience.

3. Ndoye, Daniel (2014) 'Decrease of oil prices: An opportunity to end smuggling of gas in Benin', Country Economist, Benin.

4. República de Angola (2019). relatório trimestral sobre os combustíveis, IV. Trimestre 2019

5. Banco Nacional de Angola, Relatório de Inflação,preços dos combustíveis, primeiro trimestre de 2018

6. J. BAFALA, L'industrie pétrolière en RDC, Presses de l'Université de Kinshasa, 2006

7. Présidence de la République, RDC, Ordonnance Loi nº 83-026 du 12 septembre 1983

8. Arrêté Interministériel $\mathrm{N}^{\circ}$ 002/CAB-MIN-ECON-ECOM/2009, $\mathrm{N}^{\circ}$ 001/CAB/MINHYDRO/2009 et $\mathrm{N}^{\circ} 173 / \mathrm{CAB} / \mathrm{MIN}$ -

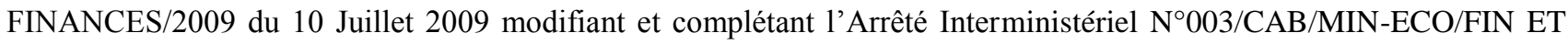
BUDG/2001et $\mathrm{N}^{\circ}$ 021/MIN/MINES-HYDRO/2001 du 25 Juin 2001 fixant les modalités de révision de la structure des prix de carburants terrestres et d'aviation

9. Arrêté ministériel n ${ }^{\circ}$ 0012/CAB/MIN/ECONAT/ABM/RKS/MSM/2020 du 12 Aout 2020 portant fixation des prix des carburants terrestres

10. Organização dos Países Exportadores de Petróleo (2012). Boletim Anual de Estatísticas

11. Ministère de l'Economie, 2017, Evolution des Structures des Prix du Javier 2012 en Aout 2017, Audit Primature, RDC 
International Journal of Advances in Scientific Research and Engineering (ijasre), Vol 7 (1), January -2021

12. Sahel, (2001) 'prospects for trade between Nigeria and its neighbors', OECD, West Africa Clu.

13. Scott, Alex (2016), 'How Chemistry Is Helping Defeat Fuel Fraud', Chemical \& Engineering News

14. HERRERAJ. 119971, Estimation des Jux illégaux d'essence nigeriane et de leur impact au Cameroun, Document de Travail DIAL, 56p

15. OSOGU B. [1996], a Issues in Petroleum Pricing in Nigeria x, Journal of Africati Economies, 4 (2) :

16. Ministère des Hydrocarbures (2018), Volume passé en Transit et Importations SOCOMS et Indépendants de 2012 à 2017, Audit Primature

17. Philippine Daily Inquirer. (6th March, 2014). "With Oil Smuggled in, Government Waves Tax Revenues

18. Ministério da Agricultura e Desenvolvimento Rural (2009) “Plano Bienal do Sector Agrário 2010/2011”, setembro

19. República de Angola (1992). Constituição da República de Angola

20. Decreto Executivo n. ${ }^{\circ} 212 / 13$, de 5 de Julho, que determina que o fornecimento de Gasóleo, destinado às actividades de pesca artesanal, semi-industrial e industrial, é feito ao preço Ex distribuição da tabela de preços dos derivados de petróleo que estiverem em vigor

21. Lei n. ${ }^{\circ}$ 28/11, de 1 de Setembro, estabelece as bases gerais de organização e funcionamento do Sistema do Sector dos Derivados do Petróleo, bem como as disposições gerais aplicáveis ao exercício das actividades de refinação do Petróleo bruto e de armazenamento, transporte, distribuição e comercialização de produtos petrolíferos

22. Decreto Executivo n ${ }^{\circ} 706 / 15$, de 30 de Dezembro - Determina que o Gasóleo passa a ter o seu preço formado no âmbito do regime dos preços livres

23. Arrêté Ministériel $\mathrm{N}^{\circ} 060 / \mathrm{CAB} / \mathrm{MIN} / \mathrm{ENERGIE} / 2006$ du 07 Octobre 2006 portant règlementation de l'activité d'importation et commercialisation des produits pétroliers 